\title{
Occurrence and distribution of ladderane oxidation products in different oceanic regimes
}

\author{
D. Rush ${ }^{1}$, E. C. Hopmans ${ }^{1}$, S. G. Wakeham ${ }^{2}{ }^{*}$, S. Schouten ${ }^{1}$, and J. S. Sinninghe Damsté ${ }^{1}$ \\ ${ }^{1}$ NIOZ Royal Netherlands Institute for Sea Research, Department of Marine Organic Biogeochemistry, P.O. Box 59, \\ 1790 AB Den Burg, Texel, The Netherlands \\ ${ }^{2}$ Skidaway Institute of Oceanography, 20 Ocean Science Circle, Savannah, GA 31411, USA \\ *now at: Department of Oceanography, University of Washington, Seattle, WA 98195-7940, USA
}

Correspondence to: D. Rush (darci.rush@nioz.nl)

Received: 15 February 2012 - Published in Biogeosciences Discuss.: 1 March 2012

Revised: 1 June 2012 - Accepted: 6 June 2012 - Published: 4 July 2012

\begin{abstract}
Ladderane fatty acids are commonly used as biomarkers for bacteria involved in anaerobic ammonium oxidation (anammox). These lipids have been experimentally shown to undergo aerobic microbial degradation to form short chain ladderane fatty acids. However, nothing is known of the production or the distribution of these oxic biodegradation products in the natural environment. In this study, we analysed marine water column particulate matter and sediment from three different oceanic regimes for the presence of ladderane oxidation products $\left(\mathrm{C}_{14}\right.$ ladderane fatty acids $)$ and of original ladderane fatty acids $\left(\mathrm{C}_{18}\right.$ and $\mathrm{C}_{20}$ ladderane fatty acids). We found that ladderane oxidation products, i.e. $\mathrm{C}_{14}$ ladderane fatty acids, are already produced within the water column of the Arabian Sea oxygen minimum zone (OMZ) and thus only low amounts of oxygen $(<3 \mu \mathrm{M})$ are needed for the $\beta$-oxidation of original ladderane fatty acids to proceed. However, no short chain ladderane fatty acids were detected in the Cariaco Basin water column, where oxygen concentrations were below detection limit, suggesting that the $\beta$-oxidation pathway is inhibited by the absence of molecular oxygen, or that the microbes performing the degradation are not proliferating under these conditions. Comparison of distributions of ladderane fatty acids indicates that short chain ladderane fatty acids are mostly produced in the water column and at the sediment surface, before being preserved deeper in the sediments. Short chain ladderane fatty acids were abundant in Arabian Sea and Peru Margin sediments (ODP Leg 201), often in higher concentrations than the original ladderane fatty acids. In a sediment core taken from within the Arabian Sea OMZ, short chain ladderanes
\end{abstract}

made up more than $90 \%$ of the total ladderanes at depths greater than $5 \mathrm{~cm}$ below sea floor. We also found short chain ladderanes in higher concentrations in hydrolysed sediment residues compared to those freely occurring in lipid extracts, suggesting that they had become bound to the sediment matrix. Furthermore, these matrix-bound short chain ladderanes were found at greater sediment depths than short chain ladderanes in the lipid extract, suggesting that binding to the sediment matrix aids the preservation of these lipids. Though sedimentary degradation of short chain ladderane fatty acids did occur, it appeared to be at a slower rate than that of the original ladderane fatty acids, and short chain ladderane fatty acids were found in sediments from the Late Pleistocene $(\sim 100 \mathrm{kyr})$. Together these results suggest that the oxic degradation products of ladderane fatty acids may be suitable biomarkers for past anammox activity in OMZs.

\section{Introduction}

Anaerobic ammonium oxidation (anammox) is the conversion of ammonium through nitrite reduction to dinitrogen gas, performed by select Planctomycetes bacteria. Since its discovery in a waste water treatment plant (Mulder et al., 1995), evidence of anammox activity has been found in anoxic marine and estuarine sediments (Jaeschke et al., 2009a; Thamdrup and Dalsgaard, 2002; Trimmer et al., 2003), as well as in the water columns of oxygen minimum zones (OMZs) (Hamersley et al., 2007; Kuypers et al., 2005; Thamdrup et al., 2006; Pitcher et al., 2011) and 
euxinic basins (Kuypers et al., 2003; Wakeham et al., 2012). Anammox has been shown to be responsible for a significant loss of nitrogen from the oceanic system, especially in OMZs (Jaeschke et al., 2007; Jensen et al., 2011), although the relative importance of anammox versus denitrification is unresolved (Lam et al., 2011; Ward et al., 2009).

Anammox bacterial cells contain characteristic biomarker lipids, called ladderane lipids, which are comprised of concatenated cyclobutane moieties (Sinninghe Damsté et al., 2002). Ladderane lipids form the outer membrane of the anammoxosome, the organelle-like structure within the bacterial cell where the anammox reaction is believed to take place. Traditionally, $\mathrm{C}_{18}$ and $\mathrm{C}_{20}$ ladderane fatty acids with either 3 or 5 cyclobutane moieties (Fig. 1, IV-VII) have been used to trace anammox (Hopmans et al., 2006; Kuypers et al., 2003, 2005; Jaeschke et al., 2009a), and the preservation of ladderane lipids in sediments may indicate past anammox activity (Jaeschke et al., 2009b). Still, relatively little is known about their fate in the water column or in the sediment.

Recently, we reported biodegradation products of $\mathrm{C}_{18}$ and $\mathrm{C}_{20}$ ladderane fatty acids that were produced during an oxic degradation experiment (Rush et al., 2011). Aerobic degradation of anammox biomass resulted in the production of short chain $\left(\mathrm{C}_{14}\right.$ and $\left.\mathrm{C}_{16}\right)$ ladderane fatty acids (Fig. 1, I-III) that were mostly likely formed via a $\beta$-oxidation pathway. This pathway has been observed previously in degradation experiments on $n$-alkyl substituted cycloalkanes (Beam and Perry, 1974; Dutta and Harayama, 2001). A preliminary investigation of a few marine sediments in this earlier study showed that biodegraded ladderane products are present in nature as well. It is unclear, however, how important they are in general, under which conditions they are formed, and if they are preserved in sediments.

Here, we investigate the occurrence and distribution of the short chain ladderane fatty acid oxidation products in suspended particulate matter (SPM) and marine sediments from different oceanic regimes where anammox activity has been shown to occur, i.e. the OMZs of the Arabian Sea (Jaeschke et al., 2007; Jensen et al., 2011) and the Peru Margin (Hamersley et al., 2007), and the euxinic Cariaco Basin (Wakeham et al., 2012). We compared the presence of the original ladderane fatty acids to that of the short chain ladderane fatty acids to determine the extent of biodegradation and the possible application of these new lipid biomarkers as tracers for past anammox activity.

\section{Materials and methods}

\subsection{Study sites and sampling methods}

Three areas (Fig. 2, Table 1) were studied: the Arabian Sea (AS), the Peru Margin (PM), and the Cariaco Basin (CB). In the AS, a series of 10 surface sediment cores down a depth profile along the Murray Ridge as well as SPM samples at
Short chain ladderane fatty acids

Original ladderane fatty acids
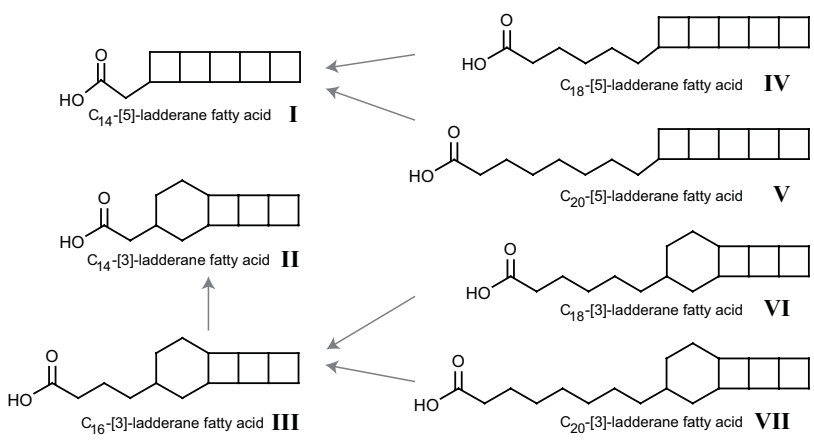

Fig. 1. Chemical structures of the ladderane lipids analysed in this study. Short chain ladderane fatty acids: (I) $\mathrm{C}_{14}$-[5]-ladderane fatty acid, (II) $\mathrm{C}_{14}$-[3]-ladderane fatty acid, (III) $\mathrm{C}_{16}$-[3]-ladderane fatty acid. Original ladderane fatty acids: (IV) $\mathrm{C}_{18}$-[5]-ladderane fatty acid, (V) $\mathrm{C}_{20}$-[5]-ladderane fatty acid, (VI) $\mathrm{C}_{18}$-[3]-ladderane fatty acid, (VII) $\mathrm{C}_{20}$-[3]-ladderane fatty acid. Two short chain ladderane fatty acids (I, II) were chosen as oxic degradation products of original ladderane fatty acids. Grey arrows indicate presumed degradation pathways.

one station were taken in the Arabian Sea on R/V Pelagia cruise 64PE301 during the northeast winter monsoon (January 2009; see Pitcher et al., 2011; Lengger et al., 2012). This ridge protrudes into the AS OMZ; surface sediment oxygen concentrations varied from minimum $(3 \mu \mathrm{M})$ on the top of the ridge to higher values $(86 \mu \mathrm{M})$ at the lower sites. Surface sediments $(0-0.5 \mathrm{~cm}$ below sea floor; $\mathrm{cm}$ b.s.f.) were sampled at ten sites. Whole sediment cores, varying in length from 20 to $32 \mathrm{~cm}$ b.s.f., were analysed at three stations (Station 1: $885 \mathrm{~m}$ water depth, within the OMZ; Station 4, $1306 \mathrm{~m}$ water depth, directly below the OMZ; and Station 10, $3003 \mathrm{~m}$ water depth, below the OMZ). On the PM, a sediment core (185.6 m b.s.f.) from the Peru shelf was sampled at $151 \mathrm{~m}$ water depth, under the major marine Peru upwelling area, during ODP Leg 201 (Site 1229; D'Hondt et al., 2003). This core is located in the Salaverry Basin, which is completely filled with hemipelagic sedimentation. Past shifts in the intensity of productivity has caused the upper boundary of the OMZ to reach the seafloor in this area (Suess et al., 1988). Finally, water column SPM samples from the CB were collected at the "Cariaco Basin time series" site (continental shelf, northern Venezuela; $10^{\circ} 30^{\prime} \mathrm{N}, 64^{\circ} 40^{\prime} \mathrm{W}$ ) in November 2007 during CARIACO cruise 139 (CAR-139; Wakeham et al., 2012). At water depths between 230 and $260 \mathrm{~m}$, both $\mathrm{O}_{2}$ and $\mathrm{H}_{2} \mathrm{~S}$ were below detection limits $(\sim 2 \mu \mathrm{M}$ and $\sim 1 \mu \mathrm{M}$, respectively). Sulfide was first detected at $260 \mathrm{~m}$ (see also Ho et al., 2004 for comparison). Euxinic deep waters in the CB are caused by the degradation of sinking organic matter produced by high primary productivity, and the limited reoxygenation of subsurface waters due to the restricted water circulation within the basin (Muller-Karger et al., 2001, 2004). 
Table 1. Location, type, and water depth of samples used in this study.

\begin{tabular}{|c|c|c|c|c|c|}
\hline Site & $\begin{array}{l}\text { Location } \\
\text { (latitude, } \\
\text { longitude) }\end{array}$ & Station & Sample Type & $\begin{array}{l}\text { Water depth } \\
\text { sampled (m) }\end{array}$ & $\begin{array}{l}\text { Sediment depth } \\
\text { sampled }\end{array}$ \\
\hline \multirow{15}{*}{$\begin{array}{l}\text { Cariaco } \\
\text { Basin } \\
(\mathrm{CB}) \\
\text { Arabian } \\
\text { Sea (AS) }\end{array}$} & $10^{\circ} 30^{\prime} 00^{\prime \prime} \mathrm{N}$, & & \multirow[t]{3}{*}{$\mathrm{SPM}^{\mathrm{a}}$} & \multirow{3}{*}{\multicolumn{2}{|c|}{$\begin{array}{l}42,205,220,236 \\
245,256,270,276 \\
296,326,346,750\end{array}$}} \\
\hline & $64^{\circ} 40^{\prime} 01^{\prime \prime} \mathrm{W}$ & & & & \\
\hline & & & & & \\
\hline & $21^{\circ} 55^{\prime} 36^{\prime \prime} \mathrm{N}$ & & \multirow[t]{2}{*}{$\mathrm{SPM}^{\mathrm{a}}$} & \multirow{2}{*}{\multicolumn{2}{|c|}{$\begin{array}{l}20,170,300,450, \\
600,750,900,1050, \\
1200,1350,1500,2000\end{array}$}} \\
\hline & $63^{\circ} 10^{\prime} 36^{\prime \prime} \mathrm{E}$ & & & & \\
\hline & $\begin{array}{l}22^{\circ} 32^{\prime} 53^{\prime \prime} \mathrm{N}, \\
64^{\circ} 02^{\prime} 23^{\prime \prime} \mathrm{E}\end{array}$ & 1 & $\begin{array}{l}\text { sediment core } \\
\left(32 \mathrm{~cm} \text { b.s.f. }{ }^{\mathrm{b}}\right)\end{array}$ & 885 & \multirow{2}{*}{$\begin{array}{l}0.5,1,1.5,2,3,4,5,6 \\
7,8,9,10,12,14,16,18 \\
20,24,28,32 \text { cm b.s.f. } \\
\text { surface }^{d}\end{array}$} \\
\hline & $\begin{array}{l}22^{\circ} 33^{\prime} 55^{\prime \prime} \mathrm{N}, \\
64^{\circ} 03^{\prime} 46^{\prime \prime} \mathrm{E}\end{array}$ & 2 & sediment core & 1013 & \\
\hline & $\begin{array}{l}22^{\circ} 19^{\prime} 55^{\prime \prime} \mathrm{N}, \\
63^{\circ} 36^{\prime} 00^{\prime \prime} \mathrm{E}\end{array}$ & 3 & sediment core & 1172 & surface $^{\mathrm{d}}$ \\
\hline & $\begin{array}{l}22^{\circ} 18^{\prime} 00^{\prime \prime} \mathrm{N}, \\
63^{\circ} 36^{\prime} 00^{\prime \prime} \mathrm{E}\end{array}$ & 4 & $\begin{array}{l}\text { sediment core } \\
(20 \mathrm{~cm} \text { b.s.f. })\end{array}$ & 1306 & \multirow{2}{*}{$\begin{array}{l}0.5,1,1.5,2,3,4,5,6 \\
7,8,9,10,12,14,16,18 \\
20 \text { cm b.s.f. }^{\text {b }} \\
\text { surface }^{\text {d }}\end{array}$} \\
\hline & $\begin{array}{l}22^{\circ} 09^{\prime} 18^{\prime \prime} \mathrm{N}, \\
63^{\circ} 12^{\prime} 45^{\prime \prime} \mathrm{E}\end{array}$ & 5 & sediment core & 1379 & \\
\hline & $\begin{array}{l}22^{\circ} 04^{\prime} 42^{\prime \prime} \mathrm{N}, \\
63^{\circ} 04^{\prime} 30^{\prime \prime} \mathrm{E}\end{array}$ & 6 & sediment core & 1495 & surface $^{\mathrm{d}}$ \\
\hline & $\begin{array}{l}22^{\circ} 18^{\prime} 30^{\prime \prime} \mathrm{N}, \\
63^{\circ} 24^{\prime} 30^{\prime \prime} \mathrm{E}\end{array}$ & 7 & sediment core & 1786 & surface $^{\mathrm{d}}$ \\
\hline & $\begin{array}{l}22^{\circ} 08^{\prime} 41^{\prime \prime} \mathrm{N}, \\
63^{\circ} 01^{\prime} 07^{\prime \prime} \mathrm{E}\end{array}$ & 8 & sediment core & 1970 & surface $^{\mathrm{d}}$ \\
\hline & $\begin{array}{l}22^{\circ} 06^{\prime} 17^{\prime \prime} \mathrm{N}, \\
62^{\circ} 53^{\prime} 42^{\prime \prime} \mathrm{E}\end{array}$ & 9 & sediment core & 2470 & surface $^{\mathrm{d}}$ \\
\hline & $\begin{array}{l}21^{\circ} 55^{\prime} 44^{\prime \prime} \mathrm{N}, \\
63^{\circ} 09^{\prime} 30^{\prime \prime} \mathrm{E}\end{array}$ & 10 & $\begin{array}{l}\text { sediment core } \\
\left(20 \mathrm{~cm} \text { b.s.f. }{ }^{\text {b }}\right)\end{array}$ & 3003 & $\begin{array}{l}0.5,1,1.5,2,3,4,5,6 \\
7,8,9,10,12,14,16,18 \\
20 \text { cm b.s.f. }\end{array}$ \\
\hline Peru Margin (PM) & $\begin{array}{l}10^{\circ} 59^{\prime} 01^{\prime \prime} \mathrm{S}, \\
77^{\circ} 57^{\prime} 47^{\prime \prime} \mathrm{W}\end{array}$ & & $\begin{array}{l}\text { sediment core } \\
(185.6 \text { m b.s.f. } \\
\text { (c) }\end{array}$ & 151 & $\begin{array}{l}0.2,0.8,6.2,6.5,7.8,11.4, \\
25.5,30.6,39.5,41.1,42.4, \\
54.7,65.4,81.5,85.6,87.1, \\
89.0,102.1,157.6, \\
185.6 \text { m b.s.f. }\end{array}$ \\
\hline
\end{tabular}

${ }^{a}$ SPM: suspended particulate matter; ${ }^{\mathrm{b}} \mathrm{cm}$ b.s.f.: centimeters below sea floor; ${ }^{\mathrm{c}} \mathrm{m}$ b.s.f.: meters below sea floor; ${ }^{\mathrm{d}}$ surface sediment: $0-0.5 \mathrm{~cm}$ b.s.f.

\subsection{Extraction}

\subsubsection{Cariaco Basin SPM}

CB water column SPM samples, collected by large-volume in situ filtration, were Soxhlet-extracted wet with dichloromentane/methanol (DCM/MeOH) as described by Wakeham et al. (1997, 2012). The total lipid extract (TLE) was dried to near-dryness using a rotary evaporator and was kept frozen at $-20^{\circ} \mathrm{C}$.

\subsubsection{Arabian Sea SPM}

AS SPM was obtained by large-volume in situ filtration and extracted as described by Pitcher et al. (2011). Briefly, freeze-dried filters were extracted using a modified BlighDyer method (Bligh and Dyer, 1959; Rattray et al., 2008). The sample was ultrasonically extracted for $15 \mathrm{~min}$ using a volume ratio of 2:1:0.8, v/v (MeOH: DCM: phosphate buffer, $\mathrm{pH}$ 7.4). The supernatant was collected and the residue was re-extracted ultrasonically two times. The solvent ratio of the combined supernatants was adjusted to 1:1:0.9 (v/v) $(\mathrm{MeOH}$ : DCM: phosphate buffer) and centrifuged. The bottom DCM layer was collected and the remaining solvent re-extracted twice with DCM. The DCM layers were combined and dried to near-dryness under rotary evaporator. The TLE was then kept frozen at $-20^{\circ} \mathrm{C}$. 

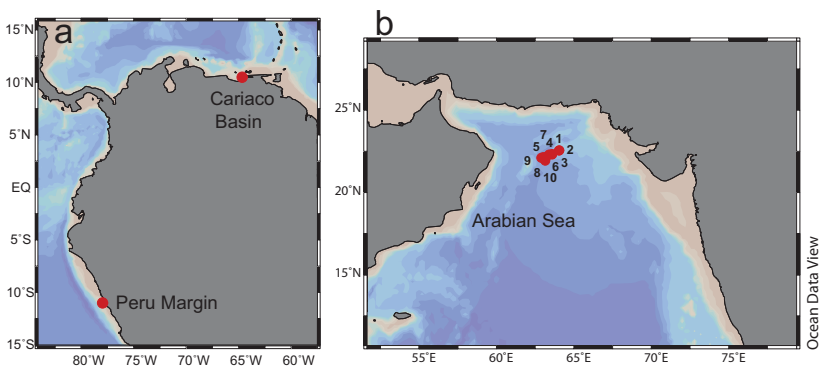

Fig. 2. Location of sampling sites. Red circles correspond to a deep sediment core (185.6 m b.s.f.) in the Peru Margin (ODP Leg 201 - Site 1229), a water column particulate matter depth profile in the Cariaco Basin (aboard the R/V Paraguachoa) and a series of surface sediments in the Arabian Sea (aboard R/V Pelagia cruise 64PE301). The Arabian particulate water column site is Station 10. Surface sediments were taken at Stations 1 through 10, located along Murray Ridge, while sediment cores of up to $32 \mathrm{~cm}$ b.s.f. depth were taken at Stations 1, 4, and 10.

\subsubsection{Arabian Sea sediments}

Slices of the first $0-0.5 \mathrm{~cm}$ of AS cores were taken on board the ship and immediately stored at $-80^{\circ} \mathrm{C}$ and transported at $-20^{\circ} \mathrm{C}$ (Lengger et al., 2012). Deeper core analyses were done on $0.5 \mathrm{~cm}$ slice intervals to $2 \mathrm{~cm}$ b.s.f. and then on $1 \mathrm{~cm}$ slice intervals to 20 or $32 \mathrm{~cm}$ b.s.f. of cores at Stations 1, 4, and 10 (Lengger et al., 2012). Freeze-dried sediments were extracted 4 times for $5 \mathrm{~min}$ by an accelerated solvent extractor (ASE 200, DIONEX) using a solvent mixture of DCM:MeOH (3:1). The effect of ASE extraction on ladderane recovery was tested using different temperatures and pressures. An extraction at relatively low temperature $\left(40^{\circ} \mathrm{C}\right)$ and high pressure $(6.9 \mathrm{MPa})$ was determined to effectively extract ladderane lipids without loss due to thermal degradation. The obtained TLEs were dried down using a Turbo Vap LV (Caliper Life Sciences) and stored at $4{ }^{\circ} \mathrm{C}$.

\subsubsection{Peru Margin sediments}

Slices of the deep core from the PM (ODP Leg 201 - Site 1229) were taken at depths of $0.2,0.8,6.2,6.5,7.8,11.4$, 25.5, 30.6, 39.5, 41.1, 42.4, 54.7, 65.4, 81.5, 85.6, 87.1, 89.0, $102.1,157.6$, and $185.6 \mathrm{~m}$ b.s.f., and extracted using the modified Bligh-Dyer method as described for the AS SPM. TLEs were stored at $-20^{\circ} \mathrm{C}$.

\subsubsection{Ladderane fatty acid work up}

Aliquots of the prepared TLEs and the PM sediment residues were saponified by refluxing with aqueous $\mathrm{KOH}$ (in $96 \%$ $\mathrm{MeOH}$ ) for $1 \mathrm{~h}$. Fatty acids were obtained by acidifying the saponified samples to a pH of 3 with $1 \mathrm{~N} \mathrm{HCl}$ in $\mathrm{MeOH}$ and extracted using DCM. The fatty acids were converted to their corresponding fatty acid methyl esters (FAMEs) by methylation with diazomethane $\left(\mathrm{CH}_{2} \mathrm{~N}_{2}\right)$. The standard practice of removing excess $\mathrm{CH}_{2} \mathrm{~N}_{2}$ by evaporation under a stream of
$\mathrm{N}_{2}$ was found to contribute to a significant loss of the volatile short chain ladderane fatty acids. Thus, $\mathrm{N}_{2}$ was not used to aid evaporation. Polyunsaturated fatty acids (PUFAs) were removed by eluting the sample over a small $\mathrm{AgNO}_{3}(5 \%)$ impregnated silica column with DCM. Fatty acid fractions were stored at $4{ }^{\circ} \mathrm{C}$ until analysis.

\subsection{HPLC/APCI-MS/MS ladderane lipid analysis}

The fatty acid fractions were dissolved in acetone, filtered through $0.45 \mu \mathrm{m}, 4 \mathrm{~mm}$ diameter PTFE filters, and analysed by HPLC/APCI-MS/MS (high performance liquid chromatography coupled to positive ion atmospheric pressure chemical ionization tandem mass spectrometry) in SRM (selective reaction monitoring) mode as originally described in Hopmans et al. (2006) and modified and expanded to include two of the short chain oxic degradation products (Rush et al., 2011). Four ladderane fatty acids (Fig. 1, IV-VII) were used in this study as indicators of the original anammox ladderane lipids from biomass. As the $\mathrm{C}_{16}$ ladderane fatty acid with 3 cyclobutane rings $\left(\mathrm{C}_{16}\right.$-[3]-ladderane fatty acid; Fig. 1, III) had been detected previously in minor amounts in an anammox enrichment culture (Rattray et al., 2010), and thus can be produced as such, it was decided to exclude the $\mathrm{C}_{16}$-[3]ladderane fatty acid SRM transition and include only the $\mathrm{C}_{14}$ ladderane fatty acid with 5 cyclobutane rings $\left(\mathrm{C}_{14}\right.$-[5]ladderane fatty acid; Fig. 1, I) and the $\mathrm{C}_{14}$-[3]-ladderane fatty acid (Fig. 1, II) in the SRM method. We assume here that de novo production of $\mathrm{C}_{14}$ ladderane fatty acids in anammox bacteria does not occur, or only in minor amounts, as observed in enrichment cultures (Rattray et al., 2010). Ladderane lipids were quantified using external calibration curves of three standards of isolated methylated ladderane fatty acids $\left(\mathrm{C}_{14}\right.$-[3]-ladderane fatty acid, $\mathrm{C}_{20}$-[3]-ladderane fatty acid, and $\mathrm{C}_{20}$-[5]-ladderane fatty acid) (Rush et al., 2011; Hopmans et al., 2006; Rattray et al., 2008). A detection limit of 30-35 pg injected was achieved with this technique. Ladderane fatty acid concentrations in sediment samples were expressed per gram of dry weight sediment $\left(\mathrm{g}^{-1}\right)$.

\section{$2.4 \quad \mathrm{NL}_{5}$}

The $\mathrm{NL}_{5}$ (iNdex of Ladderane lipids with 5 cyclobutane rings) is based on the observation that the relative length of the ladderane alkyl side chain adapts to variations in growth temperature of the anammox bacteria in cultures, as well as in the natural environment (Rattray et al., 2010). $\mathrm{NL}_{5}$ values and corresponding temperatures were calculated according to the equations of Rattray et al. (2010):

$\mathrm{NL}_{5}=\frac{\mathrm{C}_{20}-[5] \text {-ladderane fatty acid }}{\left(\mathrm{C}_{18}-[5] \text {-ladderane fatty acid }+\mathrm{C}_{20} \text {-[5]-ladderane fatty acid }\right)}$

and

$\mathrm{NL}_{5}=0.2+\frac{0.7}{1+\left(\frac{\text { Temperature-16.3 }}{1.5}\right)}$. 


\section{Results}

\subsection{Cariaco Basin water column}

As previous reported by Wakeham et al. (2012), the original $\mathrm{C}_{18}$ and $\mathrm{C}_{20}$ ladderane fatty acids were not detected within the oxic CB waters, and were only detected in SPM at $205 \mathrm{~m}$ water depth (Fig. 3a; dissolved $\mathrm{O}_{2}=18 \mu \mathrm{M}$ ), and in relatively low concentrations $\left(0.07 \mathrm{ng}^{-1}\right.$; Fig. $\left.3 \mathrm{c}\right)$. Concentrations of the unaltered, original ladderanes showed a sharp peak to $8.1 \mathrm{ng}^{-1}$ at $245 \mathrm{~m}$ (dissolved $\mathrm{O}_{2}$ below detection limit of $\sim 2 \mu \mathrm{M}$ ), which corresponded to a peak in available nutrients (Fig. 3b). Our analyses showed that short chain ladderane fatty acids were not detected in any CB SPM.

\subsection{Arabian Sea water column}

Ladderane lipid analyses of AS SPM (Fig. 4c and d) showed that the highest concentrations of original ladderane fatty acids $\left(3.3 \mathrm{ng}^{-1}\right)$ occurred in the middle of the OMZ, at $600 \mathrm{~m}$ water depth (dissolved $\mathrm{O}_{2}=3 \mu \mathrm{M}$; Fig. 4a) (Rush et al., 2012). Substantial amounts of short chain ladderane fatty acids were detected at all depths between 300 and $900 \mathrm{~m}$, with a maximum $\left(0.3 \mathrm{ng}^{-1}\right)$ occurring at $450 \mathrm{~m}$. They accounted for up to $20 \%$ of total ladderane fatty acids within the OMZ (Fig. 4d). NL5-derived temperature estimates (14 \pm $1{ }^{\circ} \mathrm{C}$; Fig. 4b) (Rush et al., 2012) corresponded to the average temperature measured by CTD $\left(12 \pm 3{ }^{\circ} \mathrm{C}\right.$; Fig. $\left.4 \mathrm{~b}\right)$ of the OMZ (Pitcher et al., 2011).

\subsection{Arabian Sea sediments}

Analyses of AS surface sediments $(0-0.5 \mathrm{~cm}$ b.s.f. $)$ along the Murray Ridge (Fig. 5a and b) showed that the highest concentrations of both original and short chain ladderane fatty acids were detected at Station 1 ( $885 \mathrm{~m}$ water depth) at the top of the ridge, within the OMZ. Concentrations of total original ladderane fatty acids were $2.4 \mu \mathrm{g} \mathrm{g}^{-1}$. Concentrations of original ladderanes fatty acids were one order of magnitude lower at Stations 2 and 3, which are still within the OMZ, but near its base. Concentrations were another order of magnitude lower just below the OMZ at Stations 4 to 6 (1306 to $1495 \mathrm{~m}$ water depth), and another order of magnitude lower at Stations 7 to 10 (Fig. 5a and b). Below the AS OMZ, original ladderane fatty acid concentrations varied from 110 to $9 \mathrm{ng} \mathrm{g}^{-1}$ for Stations 4 and 10 (3003 m water depth), respectively. Concentrations of short chain ladderane fatty acids were $4.4 \mathrm{\mu g} \mathrm{g}^{-1}$ at shallowest Station 1 and decreased down the ridge with increasing water depth, with a concentration of $0.04 \mathrm{ng} \mathrm{g}^{-1}$ at the deepest station. Beneath the OMZ, the relative proportion of short chain ladderane fatty acids increased with increasing water depth (Fig. 5b). At the deepest site sampled (Station 10), short chain ladderanes made up $80 \%$ of the total ladderane fatty acid concentration.

\section{Cariaco Basin water column}

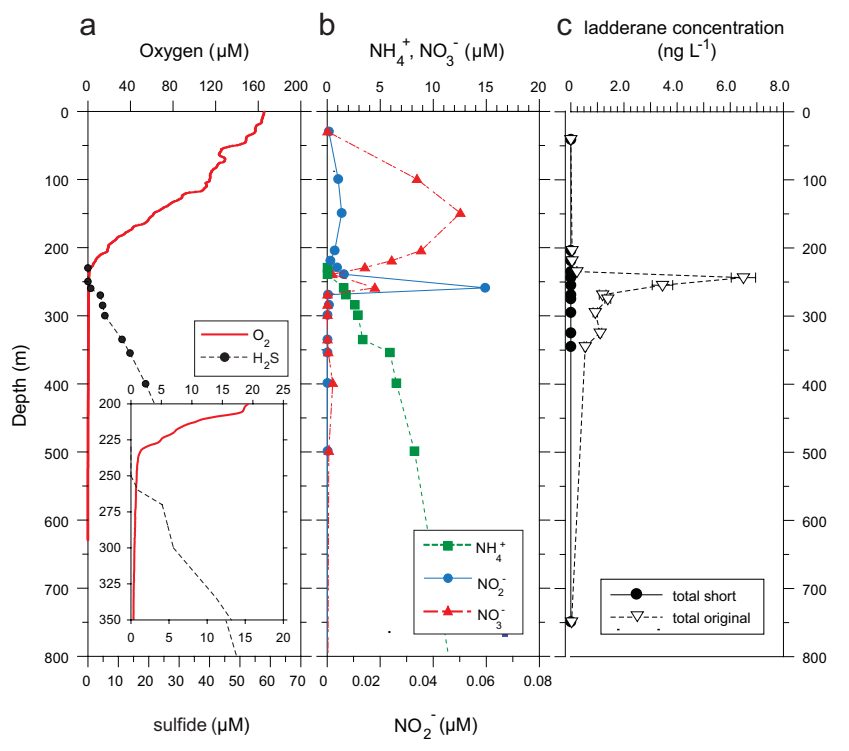

Fig. 3. (a) Oxygen (red line), $\mathrm{H}_{2} \mathrm{~S}$ (black circles), (b) $\mathrm{NH}_{4}^{+}$(green squares), $\mathrm{NO}_{2}^{-}$(blue circles), and $\mathrm{NO}_{3}^{-}$(red triangles) concentrations obtained during CTD pumping casts at the Cariaco Basin time series site during cruise 139 (CAR139). (c) Concentrations of original (open triangles) and short chain (filled circles) ladderane fatty acids were obtained from in situ pump filters. Data, except those of short chain ladderane fatty acids, from Wakeham et al. (2012).

Three AS sediment cores along Murray Ridge were also analysed for ladderane fatty acids (Fig. 6). At Station 1, within the OMZ, we observed the highest concentrations of ladderane fatty acids (Fig. 6a). The concentration of original ladderanes at the top $(0.5 \mathrm{~cm}$ b.s.f. $)$ of this core was $4.9 \mu \mathrm{g} \mathrm{g}^{-1}$ and decreased with depth down to $0.1 \mu \mathrm{g} \mathrm{g}^{-1}$ at $32 \mathrm{~cm}$ b.s.f. Short chain ladderane concentration at the top of the core was $8.0 \mu \mathrm{g} \mathrm{g}^{-1}$ and fluctuated between a minimum of $4.4 \mu \mathrm{g} \mathrm{g}^{-1}$ at $6 \mathrm{~cm}$ b.s.f., and a maximum of $10.4 \mu \mathrm{g} \mathrm{g}^{-1}$ at $9 \mathrm{~cm}$ b.s.f. The short chain ladderane fatty acids were the most abundant ladderane fatty acids (Fig. 6b), accounting for more than $60 \%$ of total ladderanes from 0.5 to $5 \mathrm{~cm}$ b.s.f. and $>90 \%$ at deeper depths. $\mathrm{NL}_{5}$-derived temperature estimates (Fig. 6c) were constant $\left(14-15^{\circ} \mathrm{C}\right)$ down the core.

At Station 4 (Fig. 6d-f), concentrations of the original ladderane fatty acids peaked at $2 \mathrm{~cm}$ b.s.f. $\left(0.58 \mu \mathrm{g} \mathrm{g}^{-1}\right)$ and decreased steadily there below. Concentrations at $20 \mathrm{~cm}$ b.s.f. were $0.02 \mu \mathrm{g} \mathrm{g}^{-1}$. Total short chain ladderane fatty acid concentrations decreased from $0.36 \mu \mathrm{gg}^{-1}$ at $0.5 \mathrm{~cm}$ b.s.f. to $0.19 \mu \mathrm{g} \mathrm{g}^{-1}$ at $20 \mathrm{~cm}$ b.s.f. Below $5 \mathrm{~cm}$ b.s.f., the short chain ladderane lipids made up more than $50 \%$ of total ladderane fatty acids. Temperature estimates from $\mathrm{NL}_{5}$ at Station 4 increased gradually from $11^{\circ} \mathrm{C}$ at the top of the core to $14^{\circ} \mathrm{C}$ at $20 \mathrm{~cm}$ b.s.f.

The concentrations of both original ladderane and short chain ladderane fatty acids at Station 10 showed a peak of 


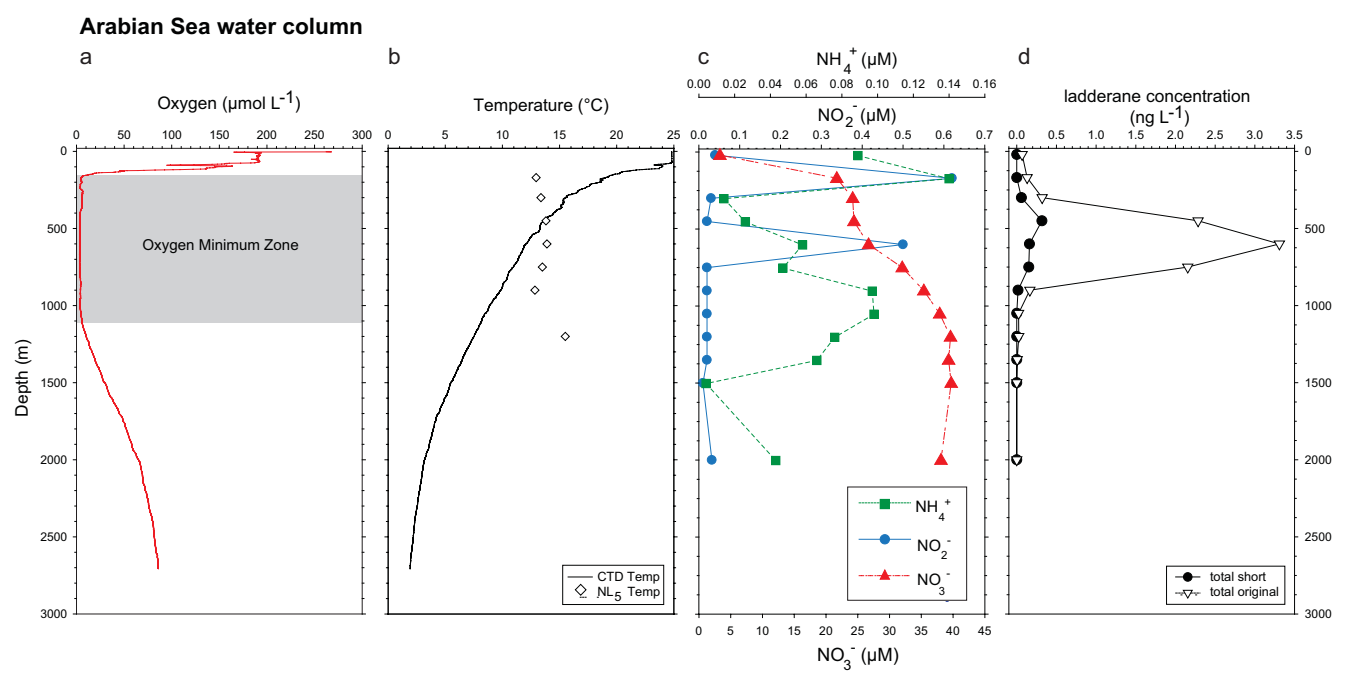

Fig. 4. Arabian Sea water column depth profiles of (a) dissolved oxygen concentrations (b) CTD measured temperature and $\mathrm{NL}_{5}$ temperature (open lozenges) derived from water column particulate matter, (c) $\mathrm{NH}_{4}^{+}$(green squares), $\mathrm{NO}_{2}^{-}$(blue circles), and $\mathrm{NO}_{3}^{-}$(red triangles) concentrations, and (d) concentrations of ladderane fatty acids (original: open triangles; short chain: filled circles). Samples were taken during R/V Pelagia cruise 64PE301. Oxygen and temperature CTD data are from Pitcher et al. (2011), and original ladderane fatty acid data are from Rush et al. (2012).

0.17 and $0.14 \mu \mathrm{gg}^{-1}$, respectively, at $3 \mathrm{~cm}$ b.s.f. (Fig. $6 \mathrm{~g}$ ). No original ladderane fatty acids were detected at 10 or $12 \mathrm{~cm}$ b.s.f. Proportionally, the short chain ladderane fatty acids were more abundant below $5 \mathrm{~cm}$ b.s.f. (Fig. $6 \mathrm{~h}$ ). $\mathrm{NL}_{5}$ derived temperatures at this depth horizon dropped from $12.5^{\circ} \mathrm{C}$ at $0.5 \mathrm{~cm}$ b.s.f. to $4.2^{\circ} \mathrm{C}$ at $4 \mathrm{~cm}$ b.s.f. (Fig. 6i). The $\mathrm{NL}_{5}$-derived temperature at $1 \mathrm{~cm}$ b.s.f. could not be calculated, as no $\mathrm{C}_{20}$-[5]-ladderane fatty acid was detected.

\subsection{Peru Margin sediments}

Twenty 1-cm-thick sediment slices down to $185.6 \mathrm{~m}$ below sea floor (mb.s.f.) on the PM were analysed, but ladderane fatty acids were only detected down to $25.5 \mathrm{mb}$ b.f. in the TLEs. Ladderane concentrations showed a maximum (Fig. $7 \mathrm{a}$ ) at the shallowest sediment ( $0.2 \mathrm{~m}$ b.s.f.), with $6 \mathrm{ng} \mathrm{g}^{-1}$ for original ladderane fatty acids and $350 \mathrm{ng} \mathrm{g}^{-1}$ for short chain ladderane fatty acids. Concentrations dropped substantially in the first $5 \mathrm{~m}$, and the deepest sediments in which ladderane fatty acids were detected in the TLEs were $0.8 \mathrm{~m}$ and $25.5 \mathrm{~m}$ b.s.f. for original ladderanes and short chain ladderanes, respectively.

Hydrolysis of PM sediment residue left after BlighDyer extraction released substantial amounts of ladderane fatty acids. Matrix-bound ladderane fatty acid concentrations (Fig. 7b; residues) were higher by at least two-fold than freely extractable ladderane fatty acids (Fig. 7a; TLEs). Matrix-bound ladderane fatty acids had maximum concentrations at $0.8 \mathrm{~m}$ b.s.f. (original ladderanes: $30 \mathrm{ng} \mathrm{g}^{-1}$; short chain ladderanes: $800 \mathrm{ng} \mathrm{g}^{-1}$ ) and were detected down to $42.4 \mathrm{~m}$ b.s.f. At all depths where ladderanes were detected, the short chain ladderane fatty acids were the most abundant $(>75 \%)$.

\section{Discussion}

\subsection{Production of short chain ladderane fatty acids}

The production of short chain ladderane fatty acids is thought to proceed via a microbially mediated $\beta$-oxidation pathway (Rush et al., 2011). If so, then the production of these biodegraded compounds in principle would require the presence of molecular oxygen (Beam and Perry, 1974; Dutta and Harayama, 2001; Koma et al., 2003). Indeed, the absence of short chain ladderane fatty acids in SPM within the anoxic and sulfidic water of the Cariaco Basin supports this. However, short chain ladderane fatty acids were detected, albeit in low relative amounts ( $<20 \%$, Fig. $4 d)$, within the oxygendepleted waters in the Arabian Sea (Fig. 4b). This suggests that only low levels of oxygen $(<3 \mu \mathrm{M}$; Pitcher et al., 2011) are required for the biodegradation pathway to proceed, that the degradation of ladderane fatty acids happens relatively quickly, i.e. already in the water column, but that degradation apparently does not occur in waters devoid of oxygen.

Short chain ladderane fatty acids occur in all AS surface and deeper sediments in substantial amounts (40-100\% of total ladderane fatty acids, Figs. 4 and 5). These short chain ladderane fatty acids could be derived from the sedimentation of those produced in the water column (Fig. 4), from the sedimentary $\beta$-oxidation of original ladderane fatty acids produced in the water column but deposited undegraded in the sediments, or of original ladderane fatty acids that were produced in the sediment itself (cf. Jaeschke et al., 2009a, 2010), as anammox has been shown to occur within anoxic sediments (Brandsma et al., 2011; Thamdrup and Dalsgaard, 2002). $\mathrm{NL}_{5}$ temperatures can be indicative of the temperature 
Arabian Sea surface sediments

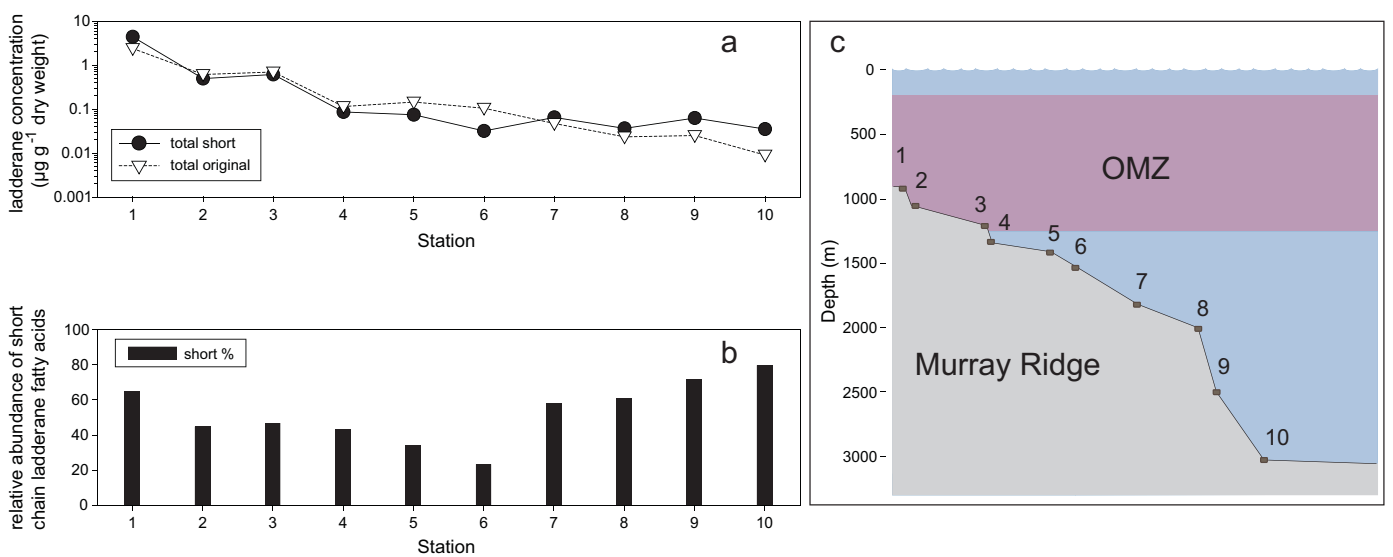

Fig. 5. (a) The concentrations (original: open triangles; short chain: filled circles) of ladderane fatty acids and (b) proportion of short chain ladderane fatty acids in surface sediment along the Murray Ridge (c), Stations 1-10 in the Arabian Sea collected during R/V Pelagia cruise 64PE301. Note the log scale in concentrations.

at which the anammox bacteria were living when their ladderane lipids were produced (Rattray et al., 2010), although caution must be used when applying this index as it has shown to be not generally applicable (Rush et al., 2012). Here we use $\mathrm{NL}_{5}$ only to highlight the differences in the origin of original ladderane fatty acids, i.e. between water column and sedimentary production, rather than apply it for accurate temperature reconstructions. $\mathrm{NL}_{5}$-derived temperatures from the AS sediment cores $\left(16 \pm 2{ }^{\circ} \mathrm{C}\right.$; Fig. $6 \mathrm{c}$, f and i) mostly correspond to temperatures within the $\mathrm{OMZ}$ water column (average CTD measured temperature of $12 \pm 3{ }^{\circ} \mathrm{C}$; Fig. 4b; Pitcher et al., 2011), but not the temperatures of the surface sediments (i.e. AS bottom waters $2-10^{\circ} \mathrm{C}$; Fig. 4 b). This suggests that most of the original ladderane lipids within the sediment were produced in the water column.

Large differences in ladderane fatty acid concentrations are observed among the AS sediment surface samples (Fig. 5a), with stations below the OMZ having much lower concentrations than those within. This is likely due to the prolonged exposure of original ladderane fatty acids to biodegrading conditions during transport through the oxygenated water column and at the sediment surface. The proportion of short chain ladderanes increases from no more than $20 \%$ in the AS water column (Fig. 4d) to up to $80 \%$ at the sediment surface (Fig. 5b). However, the degradation of original ladderanes did not translate into an accumulation of short chain ladderane fatty acids.

Though most of the original ladderane fatty acids were produced in the water column, indications of benthic production of both original and short chain ladderane fatty acids are observed at Station 10 (Fig. 6g): a peak of short chain ladderane fatty acids occurs at the same depth horizon $(2-5 \mathrm{~cm}$ b.s.f.) as a peak in original ladderane fatty acids. As anammox bacteria live in anoxic or low oxygen environments (Jaeschke et al., 2007; Kuypers et al., 2003; Thamdrup and Dalsgaard, 2002; Brandsma et al., 2011), conditions for an active anammox bacterial community are ideal near the oxycline in the sediment. Indeed, the temperatures of ladderane production calculated by $\mathrm{NL}_{5}$ at this depth horizon (Fig. 6i) decrease substantially down to $4^{\circ} \mathrm{C}$, which correspond to bottom water temperatures of Station 10, indicating in situ produced original ladderanes. The oxygen penetration depth of this core is $2 \mathrm{~cm}$ b.s.f. (Lengger et al., 2012), which indicates that oxygen may be available for the $\beta$-oxidation pathway near the depth at which ladderane fatty acids are synthesised. This suggests that the short chain ladderane concentration peak in this core is predominantly the result of oxidation of the in situ produced ladderane fatty acids, as opposed to the burial of short chain ladderanes degraded in the water column and at the sediment surface. However, the benthic production of ladderanes at $2-5 \mathrm{~cm}$ b.s.f. did not affect the $\mathrm{NL}_{5}$-derived temperatures at depths below this interval, possibly because this in situ produced material (both original and short chain ladderane fatty acids) is more readily degraded than the more resistant, older material that settled from the water column (Keil et al., 1994; Cowie et al., 1992; Middelburg, 1989).

In situ production of original ladderane fatty acids in sediments also appears to have occurred at Station 4, as we observe a peak of original ladderane fatty acids at $2 \mathrm{~cm}$ b.s.f. (Fig. 6d). In contrast to Station 10, this peak was not accompanied by a substantial increase in short chain ladderane fatty acids. In this case, oxygen possibly did not penetrate sufficiently into the sediment core (the oxygen penetration depth is $0.4 \mathrm{~cm}$; Lengger et al., 2012) for the in situ produced original ladderane fatty acids to degrade to short chain ladderane fatty acids via the $\beta$-oxidation pathway. Alternatively, the increase in concentration of original ladderane fatty acids is the 


\section{Arabian Sea sediment cores}

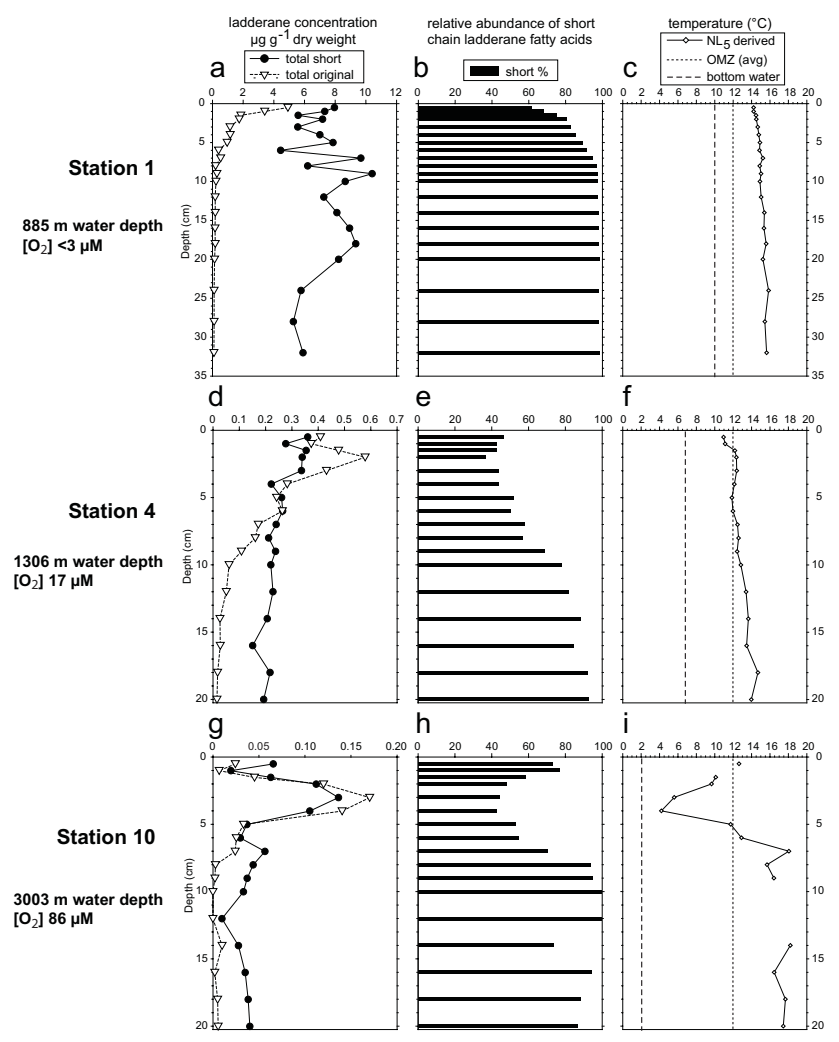

Fig. 6. Vertical distributions of concentrations of ladderane fatty acids (original: open triangles; short chain: filled circles), proportion of short chain ladderane fatty acids, and temperatures (open lozenges: $\mathrm{NL}_{5}$ - derived temperature; dotted line: oxygen minimum zone average temperature; dashed line: bottom water temperature at station) in Arabian Sea sediment cores. Station 1 (a, b, and c), Station $4(\mathbf{d}, \mathbf{e}$, and $\mathbf{f})$ and Station $10(\mathbf{g}, \mathbf{h}$, and $\mathbf{i})$. Samples were taken during R/V Pelagia cruise 64PE301.

result of past fluctuations in the flux of anammox lipids to the sea floor (i.e. resulting from an expansion or an intensification of the $\mathrm{OMZ}$ ), as no change in $\mathrm{NL}_{5}$-derived temperatures was observed at this station. This indicates that the original ladderane fatty acids were not produced in the sediment, but rather primarily in the OMZ. Thus, only specific redox conditions, i.e. low enough concentrations of oxygen for anammox to occur and high enough concentrations of oxygen for microbial degradation of ladderane fatty acids to proceed, allow for the biodegradation of in situ produced original ladderane fatty in the sediment. Therefore, short chain ladderane fatty acids in anoxic sediments are likely fossil.

\subsection{Burial and preservation of short chain ladderane fatty acids}

One of the aims of this study was to determine whether short chain ladderane fatty acids are better preserved in the sediment record than the original ladderane fatty acids that have

\section{Peru Margin sediment core}
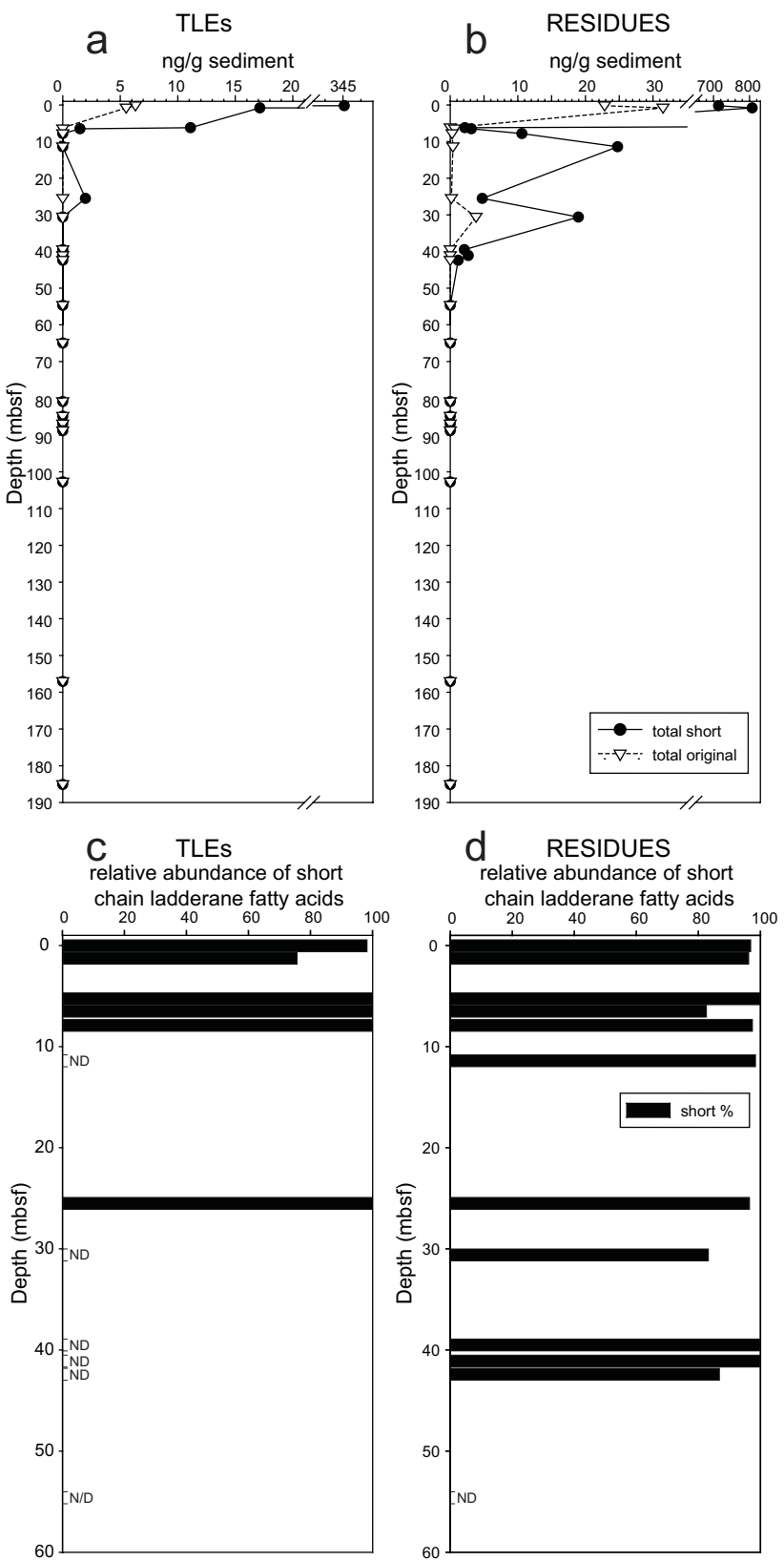

Fig. 7. Peru Margin (ODP Leg 201 - Site 1229) depth profile of deep sediment core. Freely extractable ladderane fatty acids (total lipid extracts - TLEs) and matrix-bound ladderane fatty acids (RESIDUES) were analysed. Concentrations of ladderane fatty acids in the TLE (a) and residue (b) fractions (original: open triangles; biodegraded: filled circles). No ladderane fatty acids were detected below $42.2 \mathrm{~m}$ in either the TLE or the residue fraction. Note breaks in concentration scales for both TLE and residue fractions. Proportion of short chain ladderane fatty acids in the TLE (c) and residue (d) fractions. ND: not detected. 


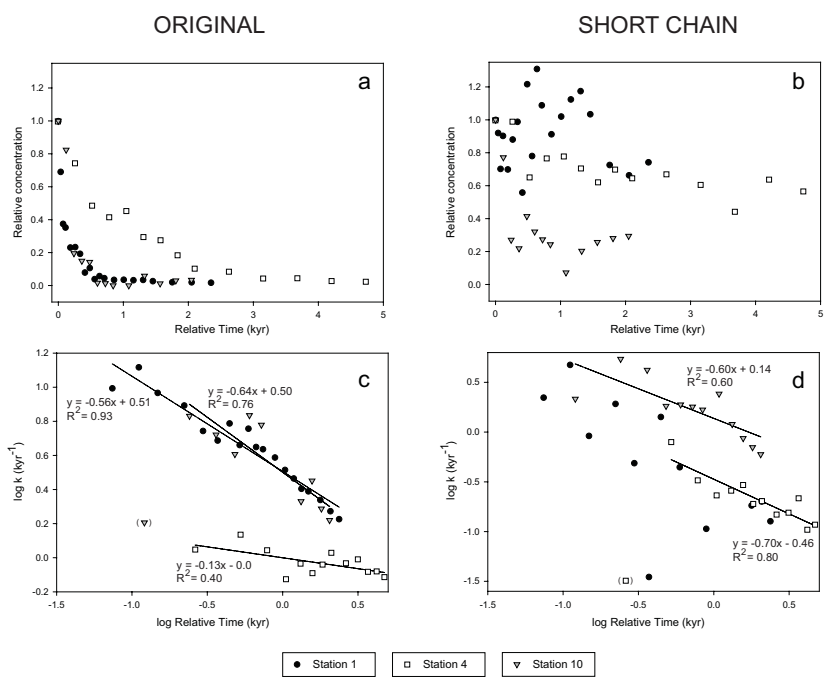

Fig. 8. Plots demonstrating the degradation of original and short chain ladderane fatty acids in three Arabian Sea sediment cores. Relative concentration (where $C_{i}=1$ ) versus relative time for (a) original ladderane fatty acids and (b) short chain ladderane fatty acids. Degradation was assumed to start from the depth of maximum original ladderane fatty acid concentrations. Correlation plot of $\log k$ versus $\log$ relative time for (c) original ladderane fatty acids and (d) short chain ladderane fatty acids. Station 1: filled circles; Station 4: open squares; Station 10: grey triangles.

been used previously as indicators of past anammox activity (Jaeschke et al., 2009b). In all cores investigated, short chain ladderane fatty acids made up $>75 \%$ of total ladderane lipids in sediments deeper than $10 \mathrm{~cm}$ b.s.f. (Figs. 6b, $\mathrm{e}, \mathrm{h}, 7 \mathrm{c}$ and $\mathrm{d}$ ), which suggests that short chain ladderane fatty acids are better preserved in sediment than the original ladderane fatty acids. The degradation of original ladderane fatty acids did not, however, result in the accumulation of short chain ladderane fatty acids. Short chain ladderane fatty acid concentrations also decreased with depth in all cores, but generally at a much slower rate than the original ladderanes (Fig. $8 \mathrm{c}$ and d). This indicates that short chain ladderane lipids are likely further anaerobically transformed, though at a slower rate than the long chain ladderane fatty acids. The products of this degradation pathway are unknown and thus it is not possible to trace anammox with biomarkers any further.

Lipids adsorbed onto the clay sediment matrix have been shown to be protected from microbial degradation and mineralisation (Hoefs et al., 2002; Hedges and Keil, 1995; Hedges et al., 2001; Ding and Henrichs, 2002; Keil et al., 1994). Therefore, we also investigated the presence of the freely extractable and of the matrix-bound (residue) ladderane fatty acids in a long core from the Peru Margin (Fig. 7). Indeed, matrix-bound ladderane fatty acids were detected down to $42.4 \mathrm{~m}$ b.s.f. but freely extractable ladderane fatty acids only down to $25.5 \mathrm{~m}$ b.s.f. (Fig. $7 \mathrm{a}$ and $\mathrm{b}$ ). This difference highlights the potential for a degree of protection by the sediment matrix, perhaps by making lipids less susceptible to microbial attack. Analyses of matrix-bound lipids could, therefore, extend the detection depth of ladderane fatty acids in the sediment record. However, more deeply buried sediments did not contain any matrix-bound ladderane fatty acids, suggesting that ultimately they are lost through diagenesis or that anammox activity was negligible at the time of deposition. Likely, fossil short chain ladderane fatty acids are too labile to be used as markers for ancient anammox in sediments older than the Late Quaternary, as we show below. Thermal degradation products of ladderane lipids (see Jaeschke et al., 2008) might be more useful biomarkers in older sediments.

Using age models available for the three AS cores (Lengger et al., 2012), we can plot the relative concentrations of original and short chain ladderane fatty acids versus relative time (Fig. 8a and b, respectively), in which relative time is the age of the sample relative to the age of maximum original ladderane fatty acid concentration $\left(t_{0}\right)$ (Station 1: $0.04 \mathrm{ka}, 0.5 \mathrm{~cm}$ b.s.f.; Station 4: $0.53 \mathrm{ka}, 2 \mathrm{~cm}$ b.s.f.; Station 10: $0.36 \mathrm{ka}, 3 \mathrm{~cm}$ b.s.f.), and relative concentration is defined as the ladderane fatty acid concentration compared to that at $t_{0}$. A strong logarithmic decrease in concentration with increasing time is observed, especially for the original ladderane fatty acids. A weaker, but still significant, decrease in relative concentration was observed for the short chain ladderane fatty acids at two stations (Stations 4 and 10; Fig. 8b). The decrease is not apparent for Station 1, where the concentration of short chain ladderane fatty acids was variable throughout the core and no significant decrease with depth was observed.

Previous studies of organic matter (OM) degradation (Middelburg, 1989; Canuel and Martens, 1996) have shown that sedimentary degradation of OM does not have a constant reactivity and the first-order degradation constant $(k)$ decreases with time. OM is considered to have several refractory and more labile portions when using a first-order type degradation model (Middelburg, 1989). This can be visualised by calculating $k$ according to Eq. (3) (Canuel and Martens, 1996):

$k=\frac{-\ln \left(\frac{C_{t}}{C_{t_{0}}}\right)}{t}$

where $t$ is relative time, $C_{t}$ is the concentration at time $t$ and $C_{t_{0}}$ is the concentration at initial time $t_{0}$. If $\log k$ is plotted against log relative time, strong correlations in the original (Fig. 8c; $R^{2}=0.40-0.93$ ) as well as the short chain (Fig. 8d; $R^{2}=0.60$ and 0.80 ) ladderane fatty acids are observed. This indicates that, as with sedimentary OM and other sedimentary organic compounds, the rate of degradation strongly decreases with time (Canuel and Martens, 1996; Middelburg, 1989; cf. Janssen, 1984). The slopes of the lines of best fit were in the same order of magnitude for the original and the short chain ladderane fatty acids, indicating that the decrease 
in reactivity follows the same trend for both classes of ladderane fatty acids. However, the intercept is lower for the short chain ladderane fatty acids $(-0.46$ and 0.14$)$ compared to the original ladderane fatty acids $(0-0.51)$, indicating that the latter are initially degraded faster than the short chain ladderane fatty acids.

Our data can potentially be used to determine at what age original and short chain ladderane fatty acid concentrations drop below detection limit $\left(\sim 200 \mathrm{pg} \mathrm{g}^{-1}\right)$ in the Arabian Sea sedimentary record, based on the correlation between $\log k$ vs. $\log$ time (Fig. $8 \mathrm{c}$ and d). For original ladderane fatty acids, the time to reach the detection limit ranged from $8-13 \mathrm{kyr}$, less than the results of Jaeschke et al. (2009b), who still detected original ladderane fatty acids in 140-ka old AS sediments. However, the time to reach the detection limit is dependent on the initial concentrations, and, therefore, for other sediment cores, the time when concentrations drop below detection limit may be different. Nevertheless, given that the surface concentrations of original ladderane fatty acids in the AS sediments are relatively high, 1-2 orders of magnitude higher than sediments from the African shelf (2-60 $\mathrm{ng} \mathrm{g}^{-1}$; Jaeschke et al., 2010) and the Irish Sea (0-20 $\mathrm{ng} \mathrm{g}^{-1}$; Jaeschke et al., 2009a), we can assume that for most sediment records, original ladderane fatty acids may rarely be detected in sediments $>10 \mathrm{kyr}$. The detection limit is reached much later for the short chain ladderane fatty acids (50 to $10^{4} \mathrm{kyr}$ ), suggesting that they degrade much slower than the original ladderane fatty acids. Indeed, in the PM core we detected short chain ladderane fatty acids to be more abundant at greater depths (Fig. 7c and d). However, in the PM core at depths $>42.4$ m b.s.f., neither short chain nor original ladderane fatty acids could be detected. This depth corresponds to a time boundary in the Late Pleistocene (Hart and Miller, 2006) and tentatively suggests that short chain ladderane fatty acids will, like the original short chain ladderane fatty acids, not be preserved beyond the Quaternary.

\section{Conclusions}

Short chain ladderane fatty acids formed by $\beta$-oxidation of original ladderane fatty acids are ubiquitous in oxygen minimum zones. Short chain ladderane fatty acids are dominantly formed in oxygen-deficient water columns, but not anoxic waters, and are further oxidised while settling through the water column and later at the sediment surface. In the sediment record, short chain biodegradation products are generally more abundant and degrade slower than the original four ladderane fatty acids used previously as biomarker for past anammox activity. Matrix-bound short chain ladderane fatty acids were detected at greater sediment depths than those that were freely extractable, and, though the biodegraded ladderanes, like the original ladderanes, are degraded in the sediment, the rate of degradation seems to be lower. In future work related to detecting past anammox activity, we propose that the residues containing matrix-bound ladderane fatty acids should also be analysed. We suggest that short chain ladderane fatty acids be considered as an alternative biomarkers for past anammox activity in Late Quaternary sediments from below OMZs.

Acknowledgements. We would like to thank G.-J. Reichart (Utrecht University), S. Lengger and A. Pitcher (Royal NIOZ), as well as the captain and crew of the R/V Pelagia for collecting samples on the PASOM Arabian Sea cruise. This research used samples provided by the Integrated Ocean Drilling Program (IODP). We thank Y. Astor and R. Varela of the Estación de Investigaciones Marinas de Margarita, Fundación La Salle de Ciencias Naturales (EDIMAR/FLASA), the captains and crews of the B/O Paraguachoa and R/V Hermano Ginés for facilitating our sampling in the Cariaco Basin, and C. Turich and D. Strâpoć for collecting the Cariaco samples. This research was partially funded by the Darwin Center for Biogeosciences (publication number DW-2012-1001). S. G. Wakeham was funded through US-NSF grant OCE0550654. SGW acknowledges the Hanse- Wissenschaftskolleg (Institute for Advanced Studies), Delmenhorst, Germany, for a fellowship in support of this project. John K. Volkman, Marcus Elvert, and Amber Hardison are thanked for their helpful comments which improved this manuscript.

Edited by: N. Ohkouchi

\section{References}

Beam, H. W. and Perry, J. J.: Microbial degradation and assimilation of alkyl-substituted cycloparaffins, J. Bacteriol., 118, 394-399, 1974.

Bligh, E. G. and Dyer, W. J.: A rapid method of total lipid extraction and purification., Can. J. Biochem. Phys., 37, 911-917, 1959.

Brandsma, J., van de Vossenberg, J., Risgaard-Petersen, N., Schmid, M. C., Engstrom, P., Eurenius, K., Hulth, S., Jaeschke, A., Abbas, B., Hopmans, E. C., Strous, M., Schouten, S., Jetten, M. S. M., and Sinninghe Damsté, J. S.: A multi-proxy study of anaerobic ammonium oxidation in marine sediments of the Gullmar Fjord, Sweden, Environmental Microbiology Reports, 3, 360366, 2011.

Canuel, E. A. and Martens, C. S.: Reactivity of recently deposited organic matter: Degradation of lipid compounds near the sediment-water interface, Geochim. Cosmochim. Ac., 60, 17931806, 1996.

Cowie, G. L., Hedges, J. I., and Calvert, S. E.: Sources and relative reactivities of amino acids, neutral sugars, and lignin in an intermittently anoxic marine environment, Geochim. Cosmochim. Ac., 56, 1963-1978, 1992.

D’Hondt, S., Jorgensen, B. B., Miller, J., and ODP Leg 201 Shipboard Scientific Party: Controls on microbial communities in deeply buried sediments, Eastern Equatorial Pacific and Peru Margin, Sites 1225-1231, Proc. ODP Init. Repts., 201, 1-32, 2003.

Ding, X. L. and Henrichs, S. M.: Adsorption and desorption of proteins and polyamino acids by clay minerals and marine sediments, Mar. Chem., 77, 225-237, 2002. 
Dutta, T. K. and Harayama, S.: Biodegradation of $n$ alkylcycloalkanes and $n$-alkylbenzenes via new pathways in Alcanivorax sp. strain MBIC 4326, Appl. Environ. Microb., 67, 1970-1974, 2001.

Hamersley, M. R., Lavik, G., Woebken, D., Rattray, J. E., Lam, P., Hopmans, E. C., Sinninghe Damsté, J. S., Krüger, S., Graco, M., Gutiérrez, D., and Kuypers, M. M. M.: Anaerobic ammonium oxidation in the Peruvian oxygen minimum zone, Limnol. Oceanogr., 52, 923-933, 2007.

Hart, D. and Miller, D. J.: Analysis and correlation of volcanic ash in marine sediments from the Peru margin, Ocean Drilling Program Leg 201: explosive volcanic cycles of the north-central Andes, Proc. ODP Sci. Results, 201, 1-43, 2006.

Hedges, J. I. and Keil, R. G.: Sedimentary organic matter preservation: an assessment and speculative synthesis, Mar. Chem., 49, 81-115, 1995.

Hedges, J. I., Baldock, J. A., Gélinas, Y., Lee, C., Peterson, M., and Wakeham, S. G.: Evidence for non-selective preservation of organic matter in sinking marine particles, Nature, 409, 801-804, 2001.

Ho, T.-Y., Taylor, G. T., Astor, Y., Varela, R., Müller-Karger, F., and Scranton, M. I.: Vertical and temporal variability of redox zonation in the water column of the Cariaco Basin: implications for organic carbon oxidation pathways, Mar. Chem., 86, 89-104, 2004.

Hoefs, M. J. L., Rijpstra, W. I. C., and Sinninghe Damsté, J. S.: The influence of oxic degradation on the sedimentary biomarker record I: Evidence from Madeira Abyssal Plain turbidites, Geochim. Cosmochim. Ac., 66, 2719-2735, 2002.

Hopmans, E. C., Kienhuis, M. V. M., Rattray, J. E., Jaeschke, A., Schouten, S., and Sinninghe Damsté, J. S.: Improved analysis of ladderane lipids in biomass and sediments using highperformance liquid chromatography/atmospheric pressure chemical ionization tandem mass spectrometry, Rapid. Commun. Mass Sp., 20, 2099-2103, 2006.

Jaeschke, A., Hopmans, E. C., Wakeham, S. G., Schouten, S., and Sinninghe Damsté, J. S.: The presence of ladderane lipids in the oxygen minimum zone of the Arabian Sea indicates nitrogen loss through anammox, Limnol. Oceanogr., 52, 780-786, 2007.

Jaeschke, A., Lewan, M. D., Hopmans, E. C., Schouten, S., and Sinninghe Damsté, J. S.: Thermal stability of ladderane lipids as determined by hydrous pyrolysis, Org. Geochem., 39, 17351741, 2008.

Jaeschke, A., Rooks, C., Trimmer, M., Nicholls, J. C., Hopmans, E. C., Schouten, S., and Sinninghe Damsté, J. S.: Comparison of ladderane phospholipid and core lipids as indicators for anaerobic ammonium oxidation (anammox) in marine sediments, Geochim. Cosmochim. Ac., 73, 2077-2088, 2009a.

Jaeschke, A., Ziegler, M., Hopmans, E. C., Reichart, G.-J., Lourens, L. J., Schouten, S., and Sinninghe Damsté, J. S.: Molecular fossil evidence for anaerobic ammonium oxidation in the Arabian Sea over the last glacial cycle, Paleoceanography, 24, 1-11, 2009b.

Jaeschke, A., Abbas, B., Zabel, M., Hopmans, E. C., Schouten, S., and Sinninghe Damsté, J. S.: Molecular evidence for anaerobic ammonium-oxidizing (anammox) bacteria in continental shelf and slope sediments off northwest Africa, Limnol. Oceanogr., 55, 365-376, 2010.

Janssen, B. H.: A simple method for calculating decomposition and accumulation of "young" soil organic matter, Plant Soil, 76, 297
304, 1984.

Jensen, M. M., Lam, P., Revsbech, N. P., Nagel, B., Gaye, B., Jetten, M. S. M., and Kuypers, M. M. M.: Intensive nitrogen loss over the Omani Shelf due to anammox coupled with dissimilatory nitrite reduction to ammonium, ISME J., 5, 1660-1670, 2011.

Keil, R. G., Montlucon, D. B., Prahl, F. G., and Hedges, J. I.: Sorptive Preservation of Labile Organic-Matter in Marine-Sediments, Nature, 370, 549-552, 1994.

Koma, D., Hasumi, F., Chung, S. Y., and Kubo, M.: Biodegradation of $n$-alkylcyclohexanes by Co-oxidation via multiple pathways in Acinetobacter sp. ODDK71, J. Biosci. Bioeng., 95, 641-644, 2003.

Kuypers, M. M. M., Sliekers, A. O., Lavik, G., Schmid, M., Jørgensen, B. B., Kuenen, J. G., Sinninghe Damsté, J. S., Strous, M., and Jetten, M. S. M.: Anaerobic ammonium oxidation by anammox bacteria in the Black Sea, Nature, 422, 608-611, 2003.

Kuypers, M. M. M., Lavik, G., Woebken, D., Schmid, M., Fuchs, B. M., Amann, R., Jørgensen, B. B., and Jetten, M. S. M.: Massive nitrogen loss from the Benguela upwelling system through anaerobic ammonium oxidation, P. Natl. Acad. Sci. USA, 102, 6478-6483, 2005.

Lam, P., Jensen, M. M., Kock, A., Lettmann, K. A., Plancherel, Y., Lavik, G., Bange, H. W., and Kuypers, M. M. M.: Origin and fate of the secondary nitrite maximum in the Arabian Sea, Biogeosciences, 8, 1565-1577, doi:10.5194/bg-8-1565-2011, 2011.

Lengger, S. K., Hopmans, E. C., Reichart, G.-J., Nierop, K. G. J., Sinninghe Damsté, J. S., and Schouten, S.: Intact and core glycerol dibiphytanyl glycerol tetraether lipids in and below the Arabian Sea oxygen minimum zone: selective preservation and degradation in sediments and consequences for the $\mathrm{TEX}_{86}$, Geochim. Cosmochim. Ac., online first: doi:10.1016/j.gca.2012.05.003, 2012.

Middelburg, J. J.: A simple rate model for organic-matter decomposition in marine-sediments, Geochim. Cosmochim. Ac., 53, 1577-1581, 1989.

Mulder, A., Van de Graaf, A. A., Robertson, L. A., and Kuenen, J. G.: Anaerobic ammonium oxidation discovered in a denitrifying fluidized-bed reactor, FEMS Microbiol. Ecol., 16, 177-183, 1995.

Muller-Karger, F., Varela, R., Thunell, R., Scranton, M., Bohrer, R., Taylor, G., Capelo, J., Astor, Y., Tappa, E., Ho, T. Y., and Walsh, J. J.: Annual cycle of primary production in the Cariaco Basin: Response to upwelling and implications for vertical export, J. Geophys. Res., 106, 4527-4542, 2001.

Muller-Karger, F., Varela, R., Thunell, R., Astor, Y., Zhang, H., Luerssen, R., and Hu, C.: Processes of coastal upwelling and carbon flux in the Cariaco Basin, Deep-Sea Res. Pt. II, 51, 927-943, 2004.

Pitcher, A., Villanueva, L., Hopmans, E. C., Schouten, S., and Sinninghe Damsté, J. S.: Niche segregation of ammonia-oxidizing archaea and anammox bacteria in the Arabian Sea oxygen minimum zone, ISME J., 5, 1896-1904, 2011.

Rattray, J. E., van de Vossenberg, J., Hopmans, E. C., Kartal, B., van Niftrik, L., Rijpstra, W. I. C., Strous, M., Jetten, M. S. M., Schouten, S., and Sinninghe Damsté, J. S.: Ladderane lipid distribution in four genera of anammox bacteria, Arch. Microbiol., 190, 51-66, 2008.

Rattray, J. E., van de Vossenberg, J., Jaeschke, A., Hopmans, E. C., Wakeham, S. G., Lavik, G., Kuypers, M. M. M., Strous, M., Jet- 
ten, M. S. M., Schouten, S., and Sinninghe Damsté, J. S.: Impact of temperature on ladderane lipid distribution in anammox bacteria, Appl. Environ. Microb., 76, 1596-1603, 2010.

Rush, D., Jaeschke, A., Hopmans, E. C., Geenevasen, J. A. J., Schouten, S., and Sinninghe Damsté, J. S.: Short chain ladderanes: Oxic biodegradation products of anammox lipids, Geochim. Cosmochim. Ac., 75, 1662-1671, 2011.

Rush, D., Wakeham, S. G., Hopmans, E. C., Schouten, S., and Sinninghe Damsté, J. S.: Biomarker evidence for anammox in the oxygen minimum zone of the Eastern Tropical North Pacific, Org. Geochem., online first: doi:10.1016/j.orggeochem.2012.02.005, 2012.

Sinninghe Damsté, J. S., Strous, M., Rijpstra, W. I. C., Hopmans, E. C., Geenevasen, J. A. J., Van Duin, A. C. T., Van Niftrik, L. A., and Jetten, M. S. M.: Linearly concatenated cyclobutane lipids form a dense bacterial membrane, Nature, 419, 708-712, 2002.

Suess, E., Von Huene, R., and ODP Leg 112 Scientific Party: Peru continental margin, Proc. ODP Init. Repts., 112, 5-23, 1988.

Thamdrup, B. and Dalsgaard, T.: Production of $\mathrm{N}_{2}$ through anaerobic ammonium oxidation coupled to nitrate reduction in marine sediments, Appl. Environ. Microb., 68, 1312-1318, 2002.
Thamdrup, B., Dalsgaard, T., Jensen, M. M., Ulloa, O., Farias, L., and Escribano, R.: Anaerobic ammonium oxidation in the oxygen-deficient waters off northern Chile, Limnol. Oceanogr., 51, 2145-2156, 2006.

Trimmer, M., Nicholls, J. C., and Deflandre, B.: Anaerobic ammonium oxidation measured in sediments along the Thames estuary, United Kingdom, Appl. Environ. Microb., 69, 6447-6454, 2003.

Wakeham, S. G., Hedges, J. I., Lee, C., Peterson, M. L., and Hernes, P. J.: Compositions and transport of lipid biomarkers through the water column and surficial sediments of the equatorial Pacific Ocean, Deep-Sea Res. Pt. II, 44, 2131-2162, 1997.

Wakeham, S. G., Turich, C., Schubotz, F., Podlaska, A., Li, X. N., Valera, R., Astor, Y., Saenz, J. P., Rush, D., Sinninghe Damsté, J. S., Summons, R. E., Scranton, M. I., Taylor, G. T., and Hinrichs, K.-U.: Biomarkers, chemistry and microbiology show chemoautotrophy in a multilayer chemocline in the Cariaco Basin, DeepSea Res. Pt. I, 63, 133-156, 2012.

Ward, B. B., Devol, A. H., Rich, J. J., Chang, B. X., Bulow, S. E., Naik, H., Pratihary, A., and Jayakumar, A.: Denitrification as the dominant nitrogen loss process in the Arabian Sea, Nature, 461, 78-81, 2009. 